Article

\title{
The Influence of Nesfatin-1 on Bone Metabolism Markers Concentration, Densitometric, Tomographic and Mechanical Parameters of Skeletal System of Rats in the Conditions of Established Osteopenia
}

\author{
Grzegorz Tymicki, Iwona Puzio *(D), Marta Pawłowska-Olszewska, Marek Bieńko (D) and Radosław Piotr Radzki
}

Citation: Tymicki, G.; Puzio, I.; Pawłowska-Olszewska, M.; Bieńko,

M.; Radzki, R.P. The Influence of Nesfatin-1 on Bone Metabolism Markers Concentration, Densitometric, Tomographic and Mechanical Parameters of Skeletal System of Rats in the Conditions of Established Osteopenia. Animals 2022, 12, 654. https://doi.org/ $10.3390 /$ ani12050654

Academic Editor: Brian Nielsen

Received: 23 December 2021

Accepted: 3 March 2022

Published: 4 March 2022

Publisher's Note: MDPI stays neutral with regard to jurisdictional claims in published maps and institutional affiliations.

Copyright: (C) 2022 by the authors. Licensee MDPI, Basel, Switzerland. This article is an open access article distributed under the terms and conditions of the Creative Commons Attribution (CC BY) license (https:// creativecommons.org/licenses/by/ $4.0 /)$.
Department of Animal Physiology, Faculty of Veterinary Medicine, University of Life Sciences in Lublin, Akademicka St. 12, 20-950 Lublin, Poland; g.tymicki@wp.pl (G.T.); martapaw@autograf.pl (M.P.-O.); marek.bienko@up.lublin.pl (M.B.); radoslaw.radzki@up.lublin.pl (R.P.R.)

* Correspondence: iwona.puzio@up.lublin.pl

Simple Summary: Nesfatin-1 is an adipokine with little known effect on the skeletal system. In this study, we examined the effect of 8-wk administration of nesfatin-1 on densitometric, tomographic, and mechanical parameters of bones, as well as the concentration of bone metabolism markers in rats with experimentally induced established osteopenia.

\begin{abstract}
Our study aimed to evaluate the impact of nesfatin-1 administration on bone metabolism and properties in established osteopenia in ovariectomized female rats. In total, 21 female Wistar rats were assigned to two groups: sham-operated (SHAM, $n=7$ ) and ovariectomized (OVA, $n=14$ ). After 12 weeks of osteopenia induction in the OVA females, the animals were given i.p. physiological saline (OVA, $n=7$ ) or $2 \mu \mathrm{g} / \mathrm{kg}$ body weight of nesfatin-1(NES, $n=7$ ) for the next 8 weeks. The SHAM animals received physiological saline at the same time. Final body weight, total bone mineral density and content of the skeleton were estimated. Then, isolated femora and tibias were subjected to densitometric, tomographic, and mechanical tests. Bone metabolism markers, i.e., osteocalcin, bone specific alkaline phosphatase (bALP), and crosslinked N-terminal telopeptide of type I collagen (NTx) were determined in serum using an ELISA kit. Ovariectomy led to negative changes in bone metabolism associated with increased resorption, thus diminishing the densitometric, tomographic, and mechanical parameters. In turn, the administration of nesfatin-1 led to an increase in the value of the majority of the tested parameters of bones. The lowest bALP concentration and the highest NTx concentration were found in the OVA females. The bALP concentration was significantly higher after nesfatin-1 administration in comparison to the OVA rats. In conclusion, the results indicate that nesfatin-1 treatment limits bone loss, preserves bone architecture, and increases bone strength in condition of established osteopenia.
\end{abstract}

Keywords: nesfatin-1; osteopenia; rat; pQCT; DXA; bone strength

\section{Introduction}

The skeleton is a dynamic, metabolically active structure that ensures movement, protection of internal organs, and maintenance of the mineral balance. In addition, bone is the target tissue for various biologically active substances that may affect its size, metabolism, and, consequently, its histological structure and strength. Bone health and strength are very important to the lifestyle of animals. They ensure the locomotion, the ability to escape, food and water access, and copulation activity. Unfortunately, lameness, leg abnormalities, and bone fractures are common in domestic and companion animals. These disorders can be associated with genetics, anatomical traits, nutrition, gut health, infectious diseases, lighting programs, movement frequency, and toxicities [1-12]. Bone disorders occurring in 
animals are, e.g., rickets, osteomalacia, osteochondrosis, osteoarthritis, dyschondroplasia, osteoporosis. [1,3,6,8,13-16]. Furthermore, bone disorders in animals are diagnosed quite late when clinical signs are present. Therefore, it is important to study the role of various factors in bone metabolism and their possible application in the treatment of animals.

In recent years, many new biologically active peptides have been identified. Some of them are adipokines released from adipose tissue. According to recent studies, adipokines are involved in bone metabolism, but their role is not fully understood [17-25]. One of the adipokines with little known effect on the skeleton is nesfatin-1 [26]. Nesfatin-1 was described by Oh-I and co-workers in 2006 as an anorexigenic 82-amino acid peptide [27]. Nesfatin-1 (AA 1-82) and other peptides, nesfatin-2 (AA 85-163) and nesfatin-3 (AA166-396), are formed from their precursor, nucleobindin-2 (NUCB2), produced by bone cells [28]. Previous studies indicated that only nesfatin- 1 exerts a biological effect $[27,29,30]$. The central and peripheral location of nesfatin- 1 has been determined. The first studies demonstrated the expression of NUCB2 mRNA and NUCB2/nesfatin-1 protein in areas of the rodent hypothalamus and brainstem related to the regulation of food intake $[27,29]$. Then, its location was affirmed in other areas of the hypothalamus, midbrain, hindbrain, sympathetic and parasympathetic spinal cord neurons [31-36]. Peripheral nesfatin-1 has been detected in the gastrointestinal tract, heart, lung, reproductive system, adipocytes, joint cartilage, and growth cartilage [37-45]. The presence of nesfatin- 1 has also been demonstrated in synovial fluid and breast milk $[40,46]$. The studies have shown that nesfatin- 1 exhibits pleiotropic activity, however in the databases there are only a few studies documenting the connection between nesfatin- 1 and the skeletal system. On the one hand, the results of in vitro and in vivo studies indicated that nesfatin-1 is associated with development of osteoarthritis (OA) $[40,47,48]$. On the other hand, nesfatin- 1 stimulated bone mineralization and inhibited osteoclastogenesis in an in vitro study [49]. The data on the influence of nesfatin-1 on bone in vivo are very limited [42,49]. Initially, $\mathrm{Li}$ and co-workers [49] demonstrated a positive changes in densitometric bone parameters after its intravenous application. In turn, a protective effect of intraperitoneal nesfatin- 1 treatment on the densitometric, tomographic, and mechanical bone parameters in developing osteopenia in female rats was shown in our earlier study [42]. Unfortunately, the studies on its influence on skeletal system are sparse and need confirmation. In order to confirm whether nesfatin-1 does exert really a positive effect on bone we intended to examine its effect in established osteopenia induced by ovariectomy in rats. The effect of nesfatin- 1 on bone tissue was studied based on the evaluation of densitomeric, tomographic and mechanical parameters of bones, as well as the concentration of bone metabolism markers.

\section{Materials and Methods}

\subsection{Animal Procedures}

The research was accepted by the 2nd Local Ethics Committee for Animal Experiments in Lublin, Poland (approval no. 23/2015).

Three-month-old healthy female Wistar rats $(n=21)$ were used in study. The initial body weight (BW) of rats was approximately $210-230 \mathrm{~g}$. During the experiment, the rats were kept in experimental plastic cages (2-3 rats) in controlled conditions at $22 \pm 2{ }^{\circ} \mathrm{C}$, with the 12/12 h day/night ratio and with lab chow (LSM, Agropol, Poland) and water available ad libitum. The access to food was limited only one night before surgery and euthanasia. After 7-d acclimatization, the rats were randomly assigned to 2 groups intended for pseudogonadectomy surgery (SHAM, $n=7$ ) and ovariectomy (OVA, $n=14$ ) according to the procedure described previously [42]. The general anesthesia was applied during the surgical operations (i.m. injection of $0.05 \mathrm{mg} / \mathrm{kg}$ BW atropinum sulphuricum, PolfaWarszawa, Poland; $3 \mathrm{mg} / \mathrm{kg}$ BW ketamine and $10 \mathrm{mg} / \mathrm{kg}$ BW xylazine, Biowet-Pulawy, Poland). After the surgery, the rats were maintained individually for several days. No postoperative complications under veterinary examinations were observed. Postoperative analgesia was not used. 
In the next step of the experiment, the animals (after pseudo-gonadectomy surgery and ovariectomy) were housed in the vivarium for 12-wks for induction of osteopenia in the ovariectomized rats. After this period, the ovariectomized rats were randomly allocated into 2 groups receiving daily by i.p. injection physiological saline $(\mathrm{PhS})(\mathrm{OVA}, n=7)$ or $2 \mu \mathrm{g} / \mathrm{kg}$ BW of nesfatin-1 (Phoenix Pharmaceuticals, Inc., Burlingame, CA, USA) (NES, $n=7)$ for 8 -wks. The SHAM animals received PhS at the same time. Nesfatin-1 was diluted in $\mathrm{PhS}(0.2 \mu \mathrm{g}$ nesfatin-1/0.1 mL PhS). The volumes of the administered solution of nesfatin-1 and PhS were corresponding. In order to eliminate the effect of nesfatin-1 on food intake, the injections were made in the morning hours up to $12 \mathrm{pm}$. During the experiment, BW of rats was assessed every two days to calculate administered nesfatin- 1 . Moreover, the feed intake was monitored.

At the end of an 8-wk experimental administration of $\mathrm{PhS}$ and nesfatin -1, the animals were weighed and then euthanized by $\mathrm{CO}_{2}$ overdose. After blood collection via intraventricular puncture, euthanasia was confirmed by cervical dislocation. Subsequently, the total skeletons were examined through dual-energy X-ray absorptiometry (DXA). Right femora and tibias were isolated, and bones cleaned of soft tissues were weighed, measured, and stored at $-20{ }^{\circ} \mathrm{C}$ for further assays.

\subsection{Bone Densitometry Measurements}

The Norland Excel Plus device (Fort Atkinson, WI, USA) and the software supplied by the manufacturer (Small Subject Scan 4.4.1) were used for DXA analysis of the total skeleton mineral content (totBMC) and mineral density (totBMD), as well as mineral content (BMC) and mineral density (BMD) of femora and tibias (Figure 1). The prescan were made at the speed of $100 \mathrm{~mm} / \mathrm{s}$ and resolution of $1.5 \times 1.5 \mathrm{~mm}$. The scan parameters were $30 \mathrm{~mm} / \mathrm{s}$ speed and $1.0 \times 1.0 \mathrm{~mm}$ resolution. The calibration of devoice was performed before each measurement cycle.

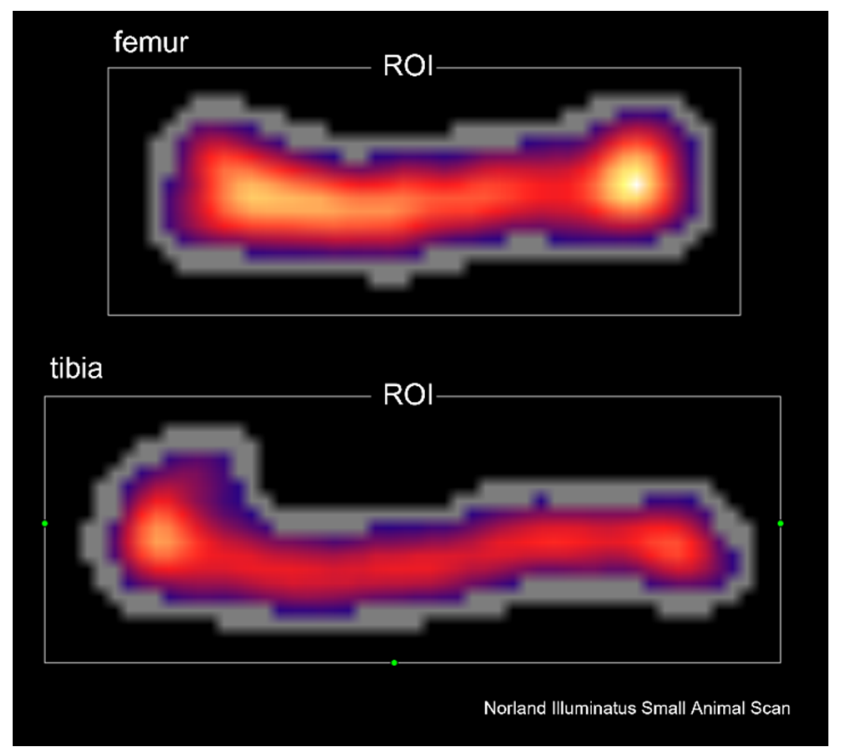

Figure 1. Representative DXA scan of femur and tibia. Abbreviations: ROI-region of interest.

\subsection{Bone Tomographic Measurements}

Femora and tibias were examined by a peripheral quantitative computed tomography (pQCT) using XCT Research SA Plus and software v.6.2.C (Stratec Medizintechnik, GmbH, Pforzheim, Germany). The trabecular bone tissue was scanned in the proximal metaphysis of the tibia and in the distal metaphysis of the femur (Figure 2) while cortical bone tissue was analyzed in the middle of the diaphysis length. The threshold was determined to be $0.630 \mathrm{~cm}^{-1}$ for trabecular bone and $0.790 \mathrm{~cm}^{-1}$ for cortical bone. The speed was set at $10 \mathrm{~mm} / \mathrm{s}$ for the initial scan and at $4 \mathrm{~mm} / \mathrm{min}$ for the measurement scan. The appa- 
ratus was calibrated before every measurement session using a quality control phantom. The tomographic parameters were determined at $50 \%$ length of the diaphysis and in the metaphyses as previously described [42].

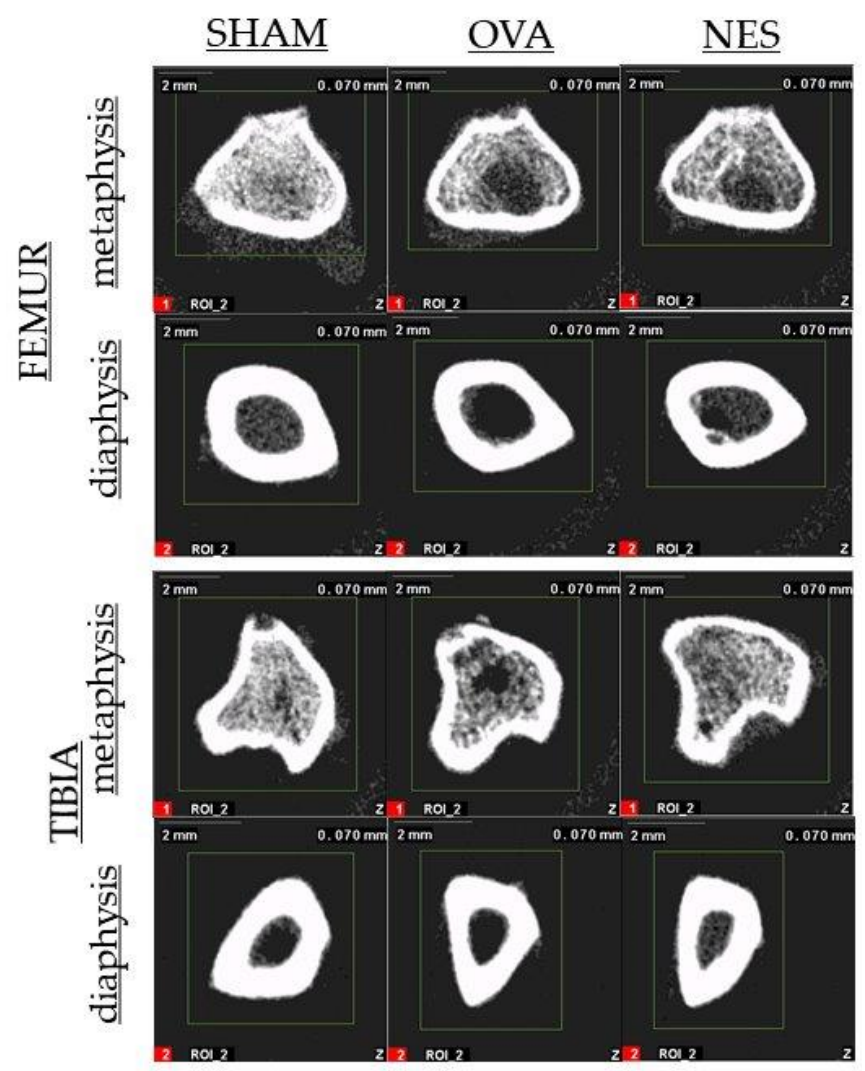

Figure 2. Representative PQCT scan of metaphysis and diaphysis of femur and tibia.

\subsection{Bone Mechanical Analysis}

Three-point bending Zwick Z010 testing system (Zwick-146 Roell GmbH \& Co., Ulm, Germany) supported by testXpert II 3.1 software was used to determine bone strength. After placing the bone on 2 supports ( $40 \%$ of the mean length of the bone), the moving head ( $1 \mathrm{kN}$, Xforce HP series) was operated perpendicularly at a constant speed $(10 \mathrm{~mm} / \mathrm{min})$ in the middle of the diaphysis [42,50]. Based on the load-displacement curve the ultimate strength, Young's modulus, and work to fracture were estimated as bone strength parameters.

\subsection{Bone Markers Analysis}

Serum concentrations of bone specific alkaline phosphatase (bALP), osteocalcin, and crosslinked N-terminal telopeptide of type I collagen (NTx) were measured using enzymelinked immunosorbent assay (ELISA) and microplate reader (Bio-Rad Laboratories Inc., Hercules, LA, USA). The commercial rat-specific kits were used in the tests (Sunred Biotechnology Company, Shanghai, China) according to the manufacturer's protocols. Serum content of calcium and phosphorus was determined spectrophotometrically using the respective commercial kits (Alphadiagnostic, Warsaw, Poland) and biochemical analyzer Mindray BS-120 (Shenzhen Mindray Bio-Medical Electronics Co., Ltd., Shenzhen, China).

\subsection{Statistical Analysis}

The values of all the parameters are reported as mean values together with S.E.M. The one-way analysis of variance (ANOVA) and the Tukey post hoc test were used to determine differences between the means. The means were exhibited statistically significant at $p \leq 0.05$. Data were analyzed using STATISTICA version 13.1 (StatSoft, Inc., Tulsa, OK, USA). 


\section{Results}

\subsection{Body Weight, Feed Intake, Bone Mass, and Length}

There were no significant differences in the BW of the rats during the treatment period (data now shown). Moreover, the assessment of rats' BW at the end of the experiment did not show statistically significant differences between the individual groups (SHAM-284.6 $\mathrm{g} \pm 10.15, \mathrm{OVA}-309.3 \mathrm{~g} \pm 21.23, \mathrm{NES}-2781 \mathrm{~g} \pm 5.69$ ). However, the highest BW values were found in the OVA rats. We did not observe a differences between studied groups in feed intake (results not shown). The SHAM rats were characterized by the greatest values of femur and tibia mass, compared to both ovariectomized groups (Table 1). Similarly, the measurements of the femur length showed the highest values of this parameter in the SHAM animals (Table 1).

Table 1. DXA parameters of whole skeleton and isolated femur and tibia of female rats after the establishment of osteopenia.

\begin{tabular}{ccccc}
\hline Parameters & SHAM & OVA & NES & $p$-Value \\
\hline totBMD & $0.155 \pm 0.002^{\mathrm{a}}$ & $0.144 \pm 0.001^{\mathrm{b}}$ & $0.153 \pm 0.002^{\mathrm{a}}$ & 0.003 \\
totBMC & $9.56 \pm 0.024$ & $8.93 \pm 0.176$ & $9.53 \pm 0.331$ & 0.192 \\
Femur & & & & \\
Mass (g) & $0.81 \pm 0.008^{\mathrm{a}}$ & $0.69 \pm 0.013^{\mathrm{b}}$ & $0.73 \pm 0.029^{\mathrm{b}}$ & 0.002 \\
Length (mm) & $35.6 \pm 0.35^{\mathrm{a}}$ & $33.7 \pm 0.17^{\mathrm{b}}$ & $34.0 \pm 0.31^{\mathrm{ab}}$ & 0.005 \\
BMD (g/mm $\left.{ }^{2}\right)$ & $0.132 \pm 0.003^{\mathrm{a}}$ & $0.112 \pm 0.002^{\mathrm{b}}$ & $0.122 \pm 0.002^{\mathrm{ab}}$ & $<0.001$ \\
BMC (g) & $0.432 \pm 0.013^{\mathrm{a}}$ & $0.344 \pm 0.007^{\mathrm{b}}$ & $0.388 \pm 0.014^{\mathrm{a}}$ & $<0.001$ \\
Tibia & & & & \\
Mass (g) & $0.59 \pm 0.016^{\mathrm{a}}$ & $0.52 \pm 0.108^{\mathrm{b}}$ & $0.53 \pm 0.023^{\mathrm{b}}$ & 0.012 \\
Length (mm) & $38.99 \pm 0.439^{\mathrm{a}}$ & $37.92 \pm 0.159$ & $38.44 \pm 0.364$ & 0.112 \\
BMD (g/mm $\left.{ }^{2}\right)$ & $0.103 \pm 0.002^{\mathrm{a}}$ & $0.089 \pm 0.002^{\mathrm{b}}$ & $0.095 \pm 0.002^{\mathrm{a}}$ & 0.002 \\
BMC (g) & $0.304 \pm 0.011^{\mathrm{a}}$ & $0.250 \pm 0.009^{\mathrm{b}}$ & $0.274 \pm 0.007^{\mathrm{a}}$ & 0.003 \\
\hline
\end{tabular}

Data are expressed as means \pm S.E.M. ( $n=7$ in each group); ${ }^{\text {a,b }}$-means within a row with unlike superscripts differ significantly. Statistically significant differences were established at $p \leq 0.05$. Abbreviations: totBMD—bone mineral density of the skeleton; totBMC—-bone mineral content of the skeleton; BMD—bone mineral density; BMC — bone mineral content.

\subsection{Bone Densitometry Measurements}

The OVA animals were characterized by statistically significant lower totBMD values in relation to the SHAM and NES females. The totBMD in the SHAM and NES females was similar (Table 1). A similar trend was found for totBMC, but the differences between the particular groups did not show statistical significance (Table 1). The ovariectomy significantly reduced the BMD and BMC of both bones, compared to the SHAM females. The values of femur BMC, as well as tibia BMD and BMC in the NES rats were significantly greater than in the OVA rats and similar to the values in the SHAM rats (Table 1).

\section{3. $p Q C T$ Analysis of Isolated Bones}

The highest values of trabecular bone parameters, i.e., T.BMC, Tv.BMD, Tb.BMC, and $\mathrm{Tb} . \mathrm{BMD}$ of the distal metaphysis of the femur were stated in the SHAM rats (Table 2), whilst the lowest values of these parameters were recorded in the OVA group. The significantly higher values of T.BMC, Totv.BMD, Tb.BMC, Tb.BMD were observed in the NES rats in relation to the OVA rats. There were no statistically significant differences in T.A and Tb.A between the groups (Table 2). Femur diaphysis of OVA rats characterized by the lowest values of T.BMD (Table 2). However, the values of this parameter in the SHAM and NES animals were similar. The results of the other tomografic parameters of femur diaphysis (T.BMC, Ctr.BMC, T.A, Ctr.A, Ctr.Th, Peri.C, Endo.C, and SSI) were similar in all groups (Table 2). 
Table 2. Femur tomographic parameters of female rats after the establishment of osteopenia.

\begin{tabular}{ccccc}
\hline Parameters & SHAM & OVA & NES & $p$-Value \\
\hline & \multicolumn{2}{c}{ Distal metaphysis } & & \\
T.BMC $(\mathrm{mg} / \mathrm{mm})$ & $15.2 \pm 0.549^{\mathrm{a}}$ & $11.4 \pm 0.211^{\mathrm{c}}$ & $12.5 \pm 0.507^{\mathrm{b}}$ & $<0.001$ \\
Tv.BMD $\left(\mathrm{mg} / \mathrm{mm}^{3}\right)$ & $808 \pm 16.84^{\mathrm{a}}$ & $652 \pm 11.17^{\mathrm{c}}$ & $670 \pm 17.57^{\mathrm{b}}$ & $<0.001$ \\
Tb.BMC $\left(\mathrm{mg} / \mathrm{mm}^{\mathrm{a}}\right)$ & $4.5 \pm 0.234^{\mathrm{a}}$ & $1.9 \pm 0.179^{\mathrm{c}}$ & $2.5 \pm 0.218^{\mathrm{b}}$ & $<0.001$ \\
Tb.BMD $\left(\mathrm{mg} / \mathrm{mm}^{3}\right)$ & $530 \pm 22.46^{\mathrm{a}}$ & $242 \pm 19.55^{\mathrm{c}}$ & $292 \pm 21.36^{\mathrm{b}}$ & $<0.001$ \\
T.A $\left(\mathrm{mm}^{2}\right)$ & $19.0 \pm 0.462$ & $17.5 \pm 0.422$ & $18.6 \pm 0.775$ & 0.182 \\
Tb.A $\left(\mathrm{mm}^{2}\right)$ & $8.6 \pm 0.205$ & $7.9 \pm 0.187$ & $8.4 \pm 0.35$ & 0.181 \\
& Diaphysis & & & \\
T.BMC $\left(\mathrm{mg} / \mathrm{mm}^{2}\right)$ & $9.9 \pm 0.191$ & $9.0 \pm 0.206$ & $9.3 \pm 0.262$ & 0.057 \\
T.BMD $\left(\mathrm{mg} / \mathrm{mm}^{3}\right)$ & $1039 \pm 14.64^{\mathrm{a}}$ & $977 \pm 13.29 \mathrm{~b}$ & $1002 \pm 13.47^{\mathrm{a}}$ & 0.009 \\
Ctr.BMC $\left(\mathrm{mg} / \mathrm{mm}^{3}\right)$ & $9.0 \pm 0.233$ & $8.4 \pm 0.213$ & $8.7 \pm 0.288$ & 0.123 \\
Ctr.BMD $\left(\mathrm{mg} / \mathrm{mm}^{3}\right)$ & $1486 \pm 4.551$ & $1485 \pm 9.378$ & $1488 \pm 3.090$ & 0.817 \\
T.A $\left.(\mathrm{mm})^{2}\right)$ & $9.7 \pm 0.148$ & $9.4 \pm 0.248$ & $9.5 \pm 0.233$ & 0.659 \\
Ctr.A $\left(\mathrm{mm}^{2}\right)$ & $6.2 \pm 0.134$ & $5.7 \pm 0.128$ & $5.8 \pm 0.201$ & 0.075 \\
Ctr.Th $\left(\mathrm{mm}^{2}\right)$ & $0.7 \pm 0.017$ & $0.6 \pm 0.011$ & $0.7 \pm 0.017$ & 0.058 \\
Peri.C $\left(\mathrm{mm}^{2}\right)$ & $11.0 \pm 0.085$ & $10.8 \pm 0.144$ & $10.9 \pm 0.132$ & 0.650 \\
Endo.C $\left(\mathrm{mm}^{3}\right)$ & $6.5 \pm 0.152$ & $6.8 \pm 0.131$ & $6.8 \pm 0.113$ & 0.263 \\
SSI $\left.(\mathrm{mm})^{3}\right)$ & $7.5 \pm 0.271$ & $6.7 \pm 0.306$ & $7.1 \pm 0.301$ & 0.214 \\
\hline
\end{tabular}

Data are expressed as means \pm S.E.M. ( $n=7$ in each group); ${ }^{\mathrm{a}, \mathrm{b}, \mathrm{c}}$-means within a row with unlike superscripts differ significantly. Statistically significant differences were established at $p \leq 0.05$. Abbrevations: T.BMC—total bone mineral content; Tv.BMD — total volumetric mineral density; Tb.BMC-trabecular bone mineral content; Tb.BMD—trabecular bone mineral density; T.A — total area; Tb.A-trabecular area; T.BMD—total mineral density; Ctr.BMC — cortical bone mineral content; Ctr.BMD—cortical bone mineral density; Ctr.A-cortical area; Ctr.Th—cortical thickness; Peri.C—-peripheral circumference; Endo.C—endocortical circumference, SSI—strength strain index.

Significantly reduced T.BMC, Tv.BMD, Tb.BMD, and Tb.BMC values of the tibia metaphysis, in comparison to those in the group of the SHAM females, were found in the OVA females (Table 3). The NES females were characterized by significantly higher Tv.BMD and Tb.BMD values than those recorded for the OVA females. The values of T.A and $\mathrm{Tb} . \mathrm{A}$ were at similar level in all examined groups (Table 3). The tibia diaphysis in the SHAM rats had significantly higher values of T.BMC, T.A, Ctr.A, Peri.C, and SSI compared to the OVA and NES groups. The Ctr.BMD and Ctr.BMC of the tibias were also higher in the SHAM rats than in the OVA rats $(p \leq 0.05)$. The values of these parameters were similar in SHAM and NES groups. The mean values of the tibia T.BMD, Ctr.Th, and Endo.C did not show statistically significant differences between the study groups (Table 3 ).

\subsection{Mechanical Parameters of Isolated Bones}

The 3-point bending test indicated a significant decrease in the values of femur ultimate strength and the work to fracture in OVA group (Table 4). The values of the abovementioned parameters in the SHAM and NES animals were similar. No significance differences were observed for femur Young's modulus between the study groups. The tibias of the NES females showed higher values of Young's modulus than the values noted in the SHAM females. The mean values of tibia ultimate strength and work to fracture did not differ significantly between the groups, although the lowest values were found in the OVA group (Table 4).

\subsection{Analysis of Bone Metabolism Markers}

The OVA animals were characterized by the lowest bALP concentration and the highest NTx concentration (Table 5). The concentration of bALP and NTx in the SHAM and NES groups were similar. The bALP concentration significantly increased in the NES group in comparison to the OVA group. No significant differences were stated in the osteocalcin level (Table 5). The concentration of serum ionized calcium and phosphorus was similar in the examined groups (Table 5). 
Table 3. Tibia tomographic parameters of female rats after the establishment of osteopenia.

\begin{tabular}{|c|c|c|c|c|}
\hline Parameters & SHAM & OVA & NES & $p$-Value \\
\hline \multicolumn{5}{|c|}{ Proximal metaphysis } \\
\hline T.BMC $(\mathrm{mg} / \mathrm{mm})$ & $14.1 \pm 0.606^{\mathrm{a}}$ & $10.0 \pm 0.280^{b}$ & $10.6 \pm 0.348^{b}$ & $<0.001$ \\
\hline Tv.BMD $\left(\mathrm{mg} / \mathrm{mm}^{3}\right)$ & $844 \pm 13.36^{a}$ & $640 \pm 20.22^{c}$ & $696 \pm 23.30^{b}$ & $<0.001$ \\
\hline Tb.BMC (mg/mm) & $4.1 \pm 0.276^{\mathrm{a}}$ & $1.2 \pm 0.056^{\mathrm{b}}$ & $1.9 \pm 0.089^{a b}$ & $<0.001$ \\
\hline Tb.BMD $\left(\mathrm{mg} / \mathrm{mm}^{3}\right)$ & $539 \pm 22.4^{\mathrm{a}}$ & $173 \pm 12.05^{\mathrm{c}}$ & $270 \pm 16.64^{b}$ & $<0.001$ \\
\hline T.A $\left(\mathrm{mm}^{2}\right)$ & $16.8 \pm 0.728$ & $15.7 \pm 0.458$ & $15.3 \pm 0.776$ & 0.319 \\
\hline Tb.A $\left(\mathrm{mm}^{2}\right)$ & $7.5 \pm 0.325$ & $7.1 \pm 0.205$ & $6.9 \pm 0.348$ & 0.327 \\
\hline \multicolumn{5}{|c|}{ Diaphysis } \\
\hline T.BMC (mg/mm) & $6.38 \pm 0.193^{\mathrm{a}}$ & $5.71 \pm 0.091^{b}$ & $5.92 \pm 0.083^{b}$ & 0.009 \\
\hline T.BMD $\left(\mathrm{mg} / \mathrm{mm}^{3}\right)$ & $1122 \pm 5.33$ & $1113 \pm 14.07$ & $1145 \pm 11.27$ & 0.104 \\
\hline Ctr.BMC (mg/mm) & $6.06 \pm 0.198^{a}$ & $5.14 \pm 0.206^{b}$ & $5.45 \pm 0.072^{a b}$ & 0.006 \\
\hline Ctr.BMD $\left(\mathrm{mg} / \mathrm{mm}^{3}\right)$ & $1449 \pm 3.96^{\mathrm{a}}$ & $1368 \pm 7.183^{b}$ & $1439 \pm 1.802^{\mathrm{a}}$ & 0.049 \\
\hline T.A $\left(\mathrm{mm}^{2}\right)$ & $5.68 \pm 0.164^{\mathrm{a}}$ & $5.17 \pm 0.081^{b}$ & $5.12 \pm 0.055^{b}$ & 0.002 \\
\hline Ctr.A $\left(\mathrm{mm}^{2}\right)$ & $4.18 \pm 0.144^{\mathrm{a}}$ & $3.76 \pm 0.048^{b}$ & $3.81 \pm 0.048^{b}$ & 0.012 \\
\hline Ctr.Th (mm) & $0.65 \pm 0.015$ & $0.62 \pm 0.011$ & $0.61 \pm 0.012$ & 0.219 \\
\hline Peri.C (mm) & $8.44 \pm 0.121^{\mathrm{a}}$ & $8.03 \pm 0.040^{b}$ & $8.05 \pm 0.029^{b}$ & 0.002 \\
\hline Endo.C (mm) & $4.35 \pm 0.032$ & $4.14 \pm 0.107$ & $4.18 \pm 0.061$ & 0.077 \\
\hline SSI $\left(\mathrm{mm}^{3}\right)$ & $3.49 \pm 0.165^{a}$ & $2.80 \pm 0.052^{b}$ & $3.01 \pm 0.033^{b}$ & 0.002 \\
\hline
\end{tabular}

Data are expressed as means \pm S.E.M. $\left(n=7\right.$ in each group); ${ }^{\mathrm{a}, \mathrm{b}, \mathrm{c}}$-means within row with unlike superscripts differ significantly. Statistically significant differences were established at $p \leq 0.05$. Abbrevations: such as Table 2 .

Table 4. Strength parameters of isolated bones of female rats after the establishment of osteopenia.

\begin{tabular}{ccccc}
\hline Parameters & SHAM & OVA & NES & $p$-Value \\
\hline & Femur & & & \\
Young's modulus (GPa) & $4.59 \pm 0.568$ & $4.56 \pm 0.295$ & $4.63 \pm 0.222$ & 0.993 \\
Ultimate strength (N) & $135 \pm 4.010^{\mathrm{a}}$ & $109 \pm 7.037^{\mathrm{b}}$ & $140 \pm 9.257^{\mathrm{a}}$ & 0.013 \\
Work to fracture (mJ) & $27.86 \pm 1.447^{\mathrm{a}}$ & $19.55 \pm 1.714^{\mathrm{b}}$ & $25.38 \pm 1.876^{\mathrm{a}}$ & 0.007 \\
& Tibia & & & \\
& $3.67 \pm 0.205^{\mathrm{a}}$ & $5.44 \pm 0.494^{\mathrm{ab}}$ & $6.05 \pm 1.003^{\mathrm{b}}$ & 0.050 \\
Young's modulus (GPa) $^{\mathrm{a}}$ & $93.45 \pm 5.27$ & $83.45 \pm 2.76$ & $97 \pm 5.02$ & 0.081 \\
Ultimate strength (N) & $20.13 \pm 2.058$ & $18.78 \pm 1.355$ & $21.48 \pm 2.07$ & 0.729 \\
Work to fracture (mJ) &
\end{tabular}

Data are expressed as means \pm S.E.M. ( $n=7$ in each group); ${ }^{\mathrm{a}, \mathrm{b}}$ - means within a row with unlike superscripts differ significantly. Statistically significant differences were established at $p \leq 0.05$.

Table 5. Serum concentration of bone metabolism markers, ionized calcium and phosphorus of female rats after the establishment of osteopenia.

\begin{tabular}{ccccc}
\hline Parameters & SHAM & OVA & NES & $p$-Value \\
\hline Osteocalcin $(\mathrm{ng} / \mathrm{mL})$ & $4.62 \pm 0.310$ & $4.87 \pm 0.240$ & $4.41 \pm 0.452$ & 0.650 \\
$\mathrm{bALP}(\mathrm{ng} / \mathrm{mL})$ & $15.422 \pm 0.793^{\mathrm{ab}}$ & $14.356 \pm 0.837^{\mathrm{a}}$ & $17.281 \pm 0.306^{\mathrm{b}}$ & 0.039 \\
$\mathrm{NTx}(\mathrm{nmol} / \mathrm{mL})$ & $23.051 \pm 0.624^{\mathrm{a}}$ & $25.376 \pm 0.536^{\mathrm{b}}$ & $24.046 \pm 0.659 \mathrm{ab}$ & 0.044 \\
$\mathrm{Ca}(\mathrm{mg} / \mathrm{dL})$ & $9.56 \pm 0.14$ & $10.44 \pm 0.49$ & $10.46 \pm 0.98$ & 0.156 \\
$\mathrm{P}(\mathrm{mg} / \mathrm{dL})$ & $8.68 \pm 0.42$ & $8.33 \pm 1.21$ & $10.67 \pm 0.67$ & 0.128 \\
\hline
\end{tabular}

Data are expressed as means \pm S.E.M. ( $n=7$ in each group); ${ }^{a}, \mathrm{~b}$-means within a row with unlike superscripts differ significantly. Statistically significant differences were established at $p \leq 0.05$. Abbreviations: bALP-bone specific alkaline phosphatase; NTx-N-terminal crosslinked telopeptide type I collagen; $\mathrm{Ca}$-calcium; $\mathrm{P}$-phosphorus.

\section{Discussion}

The present study was conducted to examine the influence of nesfatin- 1 on bone metabolism and properties in established osteopenia as a consequence of bilateral ovariectomy in female rats. This experimental procedure was intended to imitate the internal environment of deficiency of sex hormones and causing osteopenia/osteoporosis in experimental animals [51]. The decrease in estrogen levels that progresses with age or results from gonadectomy in mature individuals increases bone metabolism. The loss of ovarian 
function causes an imbalance between bone resorption and formation, which, in turn, reduces the bone mass [52-54]. Moreover, the increased bone turnover negatively influences bone microarchitecture leading to a reduction in bone strength to load and an increased risk of fracture $[55,56]$. Bone strength is determined by, e.g., the size, geometry, cortical bone porosity, trabecular bone morphology, and mineral density [57-60]. In vivo, it is indirectly estimated primarily based on BMD and BMC determined with the DXA method. In animals, the use of the DXA method in combination with special software designed for testing small animals facilitates assessment of totBMD and totBMC, as well as BMD and $\mathrm{BMC}$ for individual skeletal fragments. It has been proven that strength of bone is strongly associated with BMD, and the risk of fracture increases in individuals with low values of this parameter [61-63].

In our study, the experimental ovariectomy caused a significant reduction in femur and tibia bone mass, totBMD, BMD, and BMC values. Moreover, reduced values of the pQCT and strength parameters were observed. These results indicate predominance of bone resorption over bone synthesis, and, consequently, a reduction in bone mineralization. In turn, in the 12-week absence of the action of sex hormones, nesfatin-1 was found to mitigate the negative changes in densitometric parameters. In the ovariectomized rats receiving nesfatin-1, the BMD and BMC values were higher by $8.9 \%$ and $12.8 \%$ in the femur and by $5.4 \%$ and $9.6 \%$ in the tibia, compared to the values noted in the PhS-administered OVA rats. In addition, higher totBMD values (by 6.25\%) were found in NES animals, compared to OVA. Moreover, the values of these parameters were similar to those found in the group of females with preserved gonadal function. These results confirmed our earlier observation in a study performed in ovariectomized rats with developing osteopenia, where 8-wk i.p. administration of nesfatin-1 mitigated adverse changes in DXA parameters of tibia and femur [42]. Similarly, intravenous administration of nesfatin- 1 limited the reduction in BMD values in the study of Li et al. [49]. These authors observed an augmentation in BMD values by $5 \%$ and $10 \%$ for femur and lumbar vertebrae by $10 \%$ and $5 \%$, respectively [ 49 ].

The reduction in the negative changes in bone tissue after i.p. administration of nesfatin- 1 was confirmed by its positive effect on the tested tomographic parameters, compared to the OVA females. The mean values of the distal metaphysis of the femur were significantly increased after the nesfatin- 1 administration, i.e., by $9.65 \%$ and $2.8 \%$ for T.BMC and Tv.BMD and by $31.6 \%$ and $20.5 \%$ for Tb.BMC and Tb.BMD, respectively. In the case of the tibia, the positive effects of nesfatin- 1 were also manifested as the $8.75 \%$ and $56 \%$ increase in the Tv.BMD and Tb.BMD values, respectively, compared to the OVA group. In the case of cortical bone tissue, a significant effect of nesfatin-1 was only observed in relation to the femur T.BMD (an increase by $2.56 \%$ vs. OVA) and the tibia Ctr.BMD (an increase by $5.19 \%$ vs. OVA). This study and our previous investigations in rats with developing osteopenia [42] prove that nesfatin-1 has s a positive effect mainly on trabecular bone PQCT parameters determined in metaphyses.

In addition, the limitation of the negative changes in bone tissue as result of effects of sex hormone deficiency by nesfatin- 1 administration to the gonadectomized rats was evidenced by the enhancement in the mechanical strength. The mean value of ultimate strength and the work-to-fracture of the femur in the NES group, in comparison with the OVA group receiving $\mathrm{PhS}$, increased by $28.48 \%$ and $29.82 \%$ and these value were closer to the results obtained in the animals with preserved gonadal function. In the case of the tibia, the values of ultimate strength and the work to fracture in the NES animals were higher by $16.24 \%$ and $14.38 \%$ than in the OVA animals; however, these differences were not statistically confirmed.

In the available literature, there are papers presenting the influence of other adipokines on bone mass, DXA and tomographic parameters, and bone strength. Unfortunately, they are not explicit. Luo et al. [20] and Oshima et al. [21] reported a stimulating effect of adiponectin on osteoblasts $(\mathrm{OB})$ proliferation and differentiation, and bone mineralization. Moreover, the enhancement of trabecular bone mass, the decreased number of osteoclasts (OC), and the diminished NTx concentration suggest a positive effect of adiponectin on 
bone formation and bone mass [21]. On the other hand, negative association of adiponectin with bone mass and strength was observed in mice [18]. According to Wang et al. [64], adiponectin deficiency was found to protect against reduction in BMD and strength parameters in ovariectomized mice. However, Haugen et al. [65] reported a positive correlation between adiponectin expression and ultimate bending moment and ultimate energy absorption, and a negative correlation with bending stiffness. Moreover, adiponectin enhanced leptin, collagen, and tumor necrosis factor-alpha (TNF- $\alpha$ ) expression in OB, and stimulated OC proliferation without the influence on their functions [65].

Bone cell activity and bone metabolism can be assessed based on biochemical parameters of blood or urine, in which the concentration of so-called biochemical bone metabolism markers can be determined. These are regarded as diagnostic indicators for evaluation of bone turnover, which consists of bone formation and resorption [66]. The determination of such bone-specific proteins as osteocalcin synthesized by OB or enzymes secreted by these cells, e.g., bALP, is commonly used to assess the $\mathrm{OB}$ activity. Osteocalcin is the primary non-collagen protein in the bone matrix and a marker of osteosynthesis [67]. However, an increase in its concentration in the blood also indicates an increase in bone turnover [68]. In turn, the NTx concentration was used for assessment of OC activity and bone resorption [66]. In our studies, the changes in the bone tissue parameters were also accompanied by changes in the concentration of of NTx and bALP. The higher level of the NTx concentration in the OVA group, in comparison with the SHAM animals, indicates stimulation of bone resorption as a consequence of the ovariectomy and no impact of estrogens on the bones tissue. In turn, the rise in the bALP concentration after nesfatin- 1 administration is evidence of an increase in $\mathrm{OB}$ activity. The consequence of change in $\mathrm{OB}$ activity is the intensification of osteosynthesis confirmed in the DXA, pQCT, and mechanical tests. The simultaneous reduction in the NTx concentration by $5.4 \%$ (vs. OVA) in the NES females may indicate that nesfatin- 1 inhibits bone resorption caused by the decrease in the estrogen level. These results are in line with our previous observations [42] and confirm that nesftatin-1 participates in the metabolism of bone tissue, mediating in both osteosynthesis and resorption. However, in the study in rats with developing osteopenia, we also observed increasing concentrations of osteocalcin after nesfatin- 1 administration. In present study, no significant changes in this parameter were stated.

The osteoprotective action of estrogens on bone tissue proceeds in several ways. Estrogens affect OC activity via regulation of the relation between the receptor activator of nuclear factor kappa B ligand and osteoprotegerin (RANKL/OPG). RANKL concentration rises with decreasing levels of estrogens, which increases osteoclastogenesis and bone resorption. The osteoprotective effect of nesfatin- 1 on bone tissue in estrogen deficiency also seems to be related to RANKL, as demonstrated Li et al. in vitro studies [49]. In their research, the influence of RANKL and nesfatin-1 on the activity of RAW 264.7 murine macrophage cells, OC precursor cells, was evaluated based on measurements of the tartrateresistant acid phosphatase (TRAP) concentration, which is considered the primary marker of OC activity. It was found that nesfatin- 1 inhibited the formation of polymorphic TRAPpositive cells and decreased TRAP activity. Thus, it is highly probable that the positive effect of nesfatin- 1 on bone tissue parameters observed in present study is the result of its positive effect related to the inhibition of OC activity, which was confirmed by measurements of the NTx serum concentration.

The effects on OC activity and osteoclastogenesis have also been found in relation to other adipokines. Vaspin shows an inhibitory action on RANKL-stimulated osteoclastogenesis in vitro [19]. Chemerin deficiency inhibits differentiation of the osteoclast line [23]. Resistin induces OC formation and NF-kB promoter activity, and the expression of resistin increases with the degree of cell differentiation towards OC [24]. In turn, the effect of visfatin and adiponectin is unambiguous. On the one hand, visfatin acts as a suppressant; on the other hand, its deficiency inhibits the formation of OC [22,69]. Moreover, by induction of pro-inflammatory factors, i.e., interleukin-6 (IL-6), interleukin-8 (IL-8), and MCP-1 (monocyte chemotactic protein) in osteoblastic line cells, visfatin may 
indirectly influence OC formation [25,70]. Adiponectin has also been shown to inhibit as well as stimulate OC [20,21,71-73]. Nevertheless, despite the increased OC differentiation, no changes in OC activity under the influence of adiponectin were found either [65,73]. Adiponectin indirectly activates OC by stimulation of RANKL synthesis and inhibition of osteoprotegerin synthesis by OB $[71,74]$. Osteoprotegerin as a decoy receptor for RANKL inhibits of osteoclastogenesis and OC activity. Adiponectin can also indirectly influence OC, stimulating the synthesis of pro-inflammatory mediators, i.e., matrix metalloproteinase1, matrix metalloproteinase-13, interleukin-1, interleukin-6, interleukin-8, and monocyte chemoattractant protein- 1 by $\mathrm{OB}$ and osteoblastic line cells $[75,76]$. In addttion, nesfatin-1 stimulates pro-inflammatory mediators, i.e., cyclooxygenase-2, interleukin-6, interleukin-8, and macrophage inflammatory protein-1 $\alpha$ in osteoarthritis primary chondrocytes [48]. Based on the abovementioned data, it can be assumed that nesfatin-1, together with other adipokines, is involved in the development of pathological changes in cartilage in which pro-inflammatory factors play an important role. Rather, these results suggest a negative impact of nesfatin- 1 on the skeletal system, as pro-inflammatory cytokines participate in bone turnover and the pathogenesis of osteoporosis. They increase the activity of OC and bone resorption, leading to unfavorable changes in its structure and properties [77-80]. Taking the above into consideration, the induction of pro-inflammatory factors by nesfatin-1 may suggest its involvement in periarticular bone remodeling accompanying osteoarthritis on the one hand. In turn, considering the increased level of nesfatin- 1 in blood and synovial fluid in individuals with osteoarthritis and the increase in its synthesis in vitro induced by proinflammatory cytokines, it may be assumed that this adipokine has a protective action.

However, the positive effect of nesfatin-1 on OB manifested in the increased formation of nodules during the mineralization process was found earlier an in vitro study [49]. Alkaline phosphatase (ALP) is involved in the mineralization process, and increased activity of ALP may indicate an increase in OB activity. However, Li et al. [49] presented a rise in ALP activity in preosteoblastic cells in an in vitro study only depending on recombinant bone morphogenetic protein -2, as nesfatin-1 alone did not cause an increase in OB activity. In the present study, we found increased serum bALP level indicating an increase in the activity of $\mathrm{OB}$. This increase, combined with the improvement of tested DXA, pQCT, and strength parameters, confirms the positive influence of nesfatin-1 on bone tissue under conditions of established osteopenia.

It was found that other adipokines exerted effects on OB. Adiponectin acts directly on OB through Adipo1 and Adipo2 receptors [81]. It stimulates osteoblastogenesis by increasing the proliferation and differentiation of osteoblastic line cells and mineralization, while the OB express adiponectin $[21,73,81]$. The interaction of adiponectin is mediated by mitogen-activated kinases and bone morphogenetic protein-2 influencing OB differentiation $[20,82,83]$. Murine preosteoblasts and mature OB expressed resistin, which enhanced the proliferation of preosteoblasts in a protein kinase A (PKA)- and protein kinase C (PKC)dependent manner [24]. In primary osteoarthritis $O B$, resistin increased Wnt signaling activation, $\mathrm{OB}$ metabolic activity, and bone formation [84]. An increase in OB proliferation, collagen I synthesis, and glucose uptake, was observed in vitro under the influence of visfatin [85]. Its expression increased with the degree of OB differentiation and was associated with a higher level of nicotinamide adenine dinucleotide (NAD) [86]. Lack of visfatin or inhibition of its effect reduces the level of NAD and osteogenesis, which suggests that the differentiation of osteoblastic line cells depends on the level of NAD, and visfatin may have a regulatory action in these processes [86]. The positive effect of visfatin on bone tissue was confirmed in studies conducted by Briana et al. [87] concerning the fetal and neonatal period. Lipocalin-2 (LCN-2, syderocalin,) is synthesized by OB and chondrocytes, and the level of its expression increases with the increasing degree of cell differentiation $[17,88]$. Transgenic mice with LCN-2 overexpression showed, however, unfavorable changes in growth cartilage, reduction in the osteosynthesis rate, intensification of bone resorption, and consequent bone mass reduction and changes in its microarchitecture-mainly reduc- 
tion in bone trabeculae [17]. Moreover, chemerin found in preosteoblastic cells is likely to participate in OB differentiation [89].

Taking the above into account, the results regarding the influence of different adipokines on skeletal tissue are not conclusive and, sometimes, even contradictory. Moreover, their action takes place through various signaling pathways. Similarly, in the case of nesfatin- 1 , it is not yet possible to elucidate the precise mechanisms of its effects on bone and cartilage. On the one hand, the induction of pro-inflammatory cytokines in chondrocytes, which mediate in osteoclastogenesis, as well as the absence of changes in $\mathrm{OB}$ activity after in vitro treatment and, on the other hand, the inhibition of osteoclastogenesis in vitro and the positive effect on bone parameters in vivo necessitate further research. However, the results of DXA, pQCT and strength measurements of bones, and bone metabolism markers in the female rats with established osteopenia are undeniable.

\section{Conclusions}

Nesfatin-1 treatment limits bone loss, protects against architectural changes, and increases bone strength. The confirmed reduction in the osteopenic changes in established osteopenia suggests that exogenous nesfatin- 1 can be used to treat osteopenic disorders of skeletal system. However, further research is still needed in this area.

Author Contributions: Conceptualization, G.T. and I.P.; methodology, G.T., I.P., and M.P.-O.; validation, I.P., M.B., and R.P.R.; formal analysis, G.T., I.P., M.P.-O., M.B., and R.P.R.; investigation, G.T., I.P., and M.P.-O.; data curation, G.T. and I.P.; writing-original draft preparation, G.T. and I.P.; writing-review and editing, G.T. and I.P.; supervision, I.P.; project administration, G.T. and I.P. All authors have read and agreed to the published version of the manuscript.

Funding: This research received no external funding.

Institutional Review Board Statement: The study was conducted according to the guidelines of the Declaration of Helsinki, and approved by the 2nd Local Animal Welfare Committee at the University of Life Sciences in Lublin, Poland (approval no. 23/2015).

Informed Consent Statement: Not applicable.

Data Availability Statement: The data presented in this study are available on request from the corresponding author.

Acknowledgments: The authors thank Jolanta Stec for help in biochemical analyzes.

Conflicts of Interest: The authors declare that they no conflict interest.

\section{References}

1. Campbell, D.L.M. Skeletal health of layers across all housing systems and future research directions for Australia. Anim. Prod. Sci. 2021, 61, 883-892. [CrossRef]

2. Gomes Neto, J.; Gauger, P.; Strait, E.; Boyes, N.; Madson, D.; Schwartz, K. Mycoplasma-associated arthritis: Critical points for diagnosis. J. Swine Health Prod. 2012, 20, 82-86.

3. Jahejo, A.J.; Tian, W.X. Cellular, molecular and genetical overview of avian tibial dyschondroplasia. Res. Vet. Sci. 2021, 135, 569-579. [CrossRef] [PubMed]

4. Karaarslan, S.; Nazlıgül, A. Effects of lighting, stocking density, and access to perches on leg health variables as welfare indicators in broiler chickens. Liv. Sci. 2018, 218, 31-36. [CrossRef]

5. Mostafa, M.B.; Elemmawy, Y.M. Relationships between morphometric measurements and musculoskeletal disorders in jumping Thoroughbred horses. J. Equine Sci. 2020, 31, 23-27. [CrossRef] [PubMed]

6. Olstad, K.; Ekman, S.; Carlson, C.S. An update on the pathogenesis of osteochondrosis. Vet. Pathol. 2015, 52, 785-802. [CrossRef]

7. Shim, M.Y.; Karnuah, A.B.; Mitchell, A.D.; Anthony, N.B.; Pesti, G.M.; Aggrey, S.E. The effects of growth rate on leg morphology and tibia breaking strength, mineral density, mineral content, and bone ash in broilers. Poult. Sci. 2012, 91, 1790-1795. [CrossRef]

8. Thompson, K. Bones and joints. In Pathology of Domestic Animals, 5th ed.; Maxie, M.G., Ed.; Elsevier: Philadelphia, PA, USA, 2007; pp. 1-184.

9. VanRiet, M.M.J.; Millet, S.; Aluwé, M.; Janssens, G.P.J. Impact of nutrition on lameness and claw health in sows. Liv. Sci. 2013, 156, 24-35. [CrossRef] 
10. Wegner, B.; Tenhündfeld, J.; Vogels, J.; Beumer, M.; Kamphues, J.; Hansmann, F.; Rieger, H.; Grosse Beilage, E.; Hennig-Pauka, I. Lameness in fattening pigs-Mycoplasma hyosynoviae, osteochondropathy and reduced dietary phosphorus level as three influencing factors: A case report. Porc. Health Manag. 2020, 6, 41. [CrossRef]

11. Ytrehus, B.; Carlson, C.S.; Ekman, S. Etiology and pathogenesis of osteochondrosis. Vet. Pathol. 2007, 44, 429-448. [CrossRef]

12. Zhao, S.C.; Teng, X.Q.; Xu, D.L.; Chi, X.; Ge, M.; Xu, S.W. Influences of low level of dietary calcium on bone characters in laying hens. Poul. Sci. 2020, 99, 7084-7091. [CrossRef] [PubMed]

13. Crenshaw, T.D. Arthritis or OCD-identification and prevention. Adv. Pork Prod. 2006, 17, 199-208.

14. Olstad, K.; Wormstrand, B.; Kongsro, J.; Grindflek, E. Osteochondrosis in the distal femoral physis of pigs starts with vascular failure. Vet. Pathol. 2019, 56, 732-742. [CrossRef] [PubMed]

15. Schild, C.O.; Boabaid, F.M.; Olivera, L.G.S.; Machado, M.; Vildoza, A.; Saravia, A.; Custodio, A.; Command, C.; Martinez, A.; Jaurena, M.; et al. Osteomalacia as a result of phosphorus deficiency in beef cattle grazing subtropical native pastures in Uruguay. J. Vet. Diagn. Invest. 2021, 33, 1018-1022. [CrossRef] [PubMed]

16. VanTurnhout, M.C.; Schipper, H.; van Lagen, B.; Zuilhof, H.; Kranenbarg, S.; van Leeuwen, J.L. Postnatal development of depth-dependent collagen density in ovine articular cartilage. BMC Dev. Biol. 2010, 10, 108.

17. Costa, D.; Lazzarini, E.; Canciani, B.; Giuliani, A.; Spano, R.; Marozzi, K.; Manescu, A.; Cancedda, R.; Tavella, S. Altered bone development and turnover in transgenic mice over-expressing lipocalin-2 in bone. J. Cell Physiol. 2013, 228, 2210-2221. [CrossRef]

18. Ealey, K.N.; Kaludjerovic, J.; Archer, M.C.; Ward, W.E. Adiponectin is a negative regulator of bone mineral and bone strength in growing mice. Exp. Biol. Med. 2008, 233, 1546-1553. [CrossRef]

19. Kamio, N.; Kawato, T.; Tanabe, N.; Kitami, S.; Morita, T.; Ochiai, K.; Maeno, M. Vaspin attenuates RANKL-induced osteoclast formation in RAW264.7 cells. Connect. Tissue Res. 2013, 54, 147-152. [CrossRef]

20. Luo, X.H.; Guo, L.J.; Yuan, L.Q.; Xie, H.; Zhou, H.D.; Wu, X.P.; Lia, R.Y. Adiponectin stimulates human osteoblasts proliferation and differentiation via the MAPK signaling pathway. Exp. Cell Res. 2005, 309, 99-109. [CrossRef]

21. Oshima, K.; Nampei, A.; Matsuda, M.; Iwaki, M.; Fukuhara, A.; Hashimoto, J.; Yoshikawa, H.; Shimomura, I. Adiponectin increases bone mass by suppressing osteoclast and activating osteoblast. Biochem. Biophys. Res. Commun. 2005, 331, 520-526. [CrossRef]

22. Moschen, A.R.; Geiger, S.; Gerner, R.; Tilg, H. Pre-B cell colony enhancing factor/NAMPT/visfatin and its role in inflammationrelated bone disease. Mutat. Res. 2010, 690, 95-101. [CrossRef] [PubMed]

23. Muruganandan, S.; Dranse, H.J.; Rourke, J.L.; McMullen, N.M.; Sinal, C.J. Chemerin neutralization blocks hematopoietic stem cell osteoclastogenesis. Stem Cells 2013, 31, 2172-2182. [CrossRef] [PubMed]

24. Thommesen, L.; Stunes, A.K.; Monjo, M.; Grøsvik, K.; Tamburstuen, M.V.; Kjøbli, E.; Lyngstadaas, S.P.; Reseland, J.E.; Syversen, U. Expression and regulation of resistin in osteoblasts and osteoclasts indicate a role in bone metabolism. J. Cell Biochem. 2006, 99, 824-834. [CrossRef] [PubMed]

25. Tsiklauri, L.; Werner, J.; Kampschulte, M.; Frommer, K.W.; Berninger, L.; Irrgang, M.; Glenske, K.; Hose, D.; El Khassawna, T.; Pons-Kühnemann, J.; et al. Visfatin alters the cytokine and matrix-degrading enzyme profile during osteogenic and adipogenic MSC differentiation. Osteoarth. Cartil. 2018, 26, 1225-1235. [CrossRef]

26. Ramanjaneya, M.; Chen, J.; Brown, J.E.; Tripathi, G.; Hallschmid, M.; Patel, S.; Kern, W.; Hillhouse, E.W.; Lehnert, H.; Tan, B.K. Identification of nesfatin-1 in human and murine adipose tissue: A novel depot-specific adipokine with increased levels in obesity. Endocrinology 2010, 151, 3169-3180. [CrossRef]

27. Oh-I, S.; Shimizu, H.; Satoh, T.; Okada, S.; Adachi, S.; Inoue, K.; Eguchi, H.; Yamamoto, M.; Imaki, T.; Hashimoto, K.; et al. Identification of nesfatin-1 as a satiety molecule in the hypothalamus. Nature 2006, 443, 709-712.

28. Petersson, U.; Somogyi, E.; Reinholt, F.P.; Karlsson, T.; Sugars, R.V.; Wendel, M. Nucleobindin is produced by bone cells and secreted into the osteoid, with a potential role as a modulator of matrix maturation. Bone 2004, 34, 949-960. [CrossRef]

29. Shimizu, H.; Oh-i, S.; Hashimoto, K.; Nakata, M.; Yamamoto, S.; Yoshida, N.; Eguchi, H.; Kato, I.; Inoue, K.; Satoh, T.; et al Peripheral administration of nesfatin-1 reduces food intake in mice: The leptin-independent mechanism. Endocrinology 2009, 150, 662-671. [CrossRef]

30. Stengel, A.; Goebel-Stengel, M.; Wang, L.; Kato, I.; Mori, M.; Taché, Y. Nesfatin-1 $130-59$ but not the N- and C-terminal fragments, nesfatin- $1_{1-29}$ and nesfatin- $1_{60-82}$ injected intracerebroventricularly decreases dark phase food intake by increasing inter-meal intervals in mice. Peptides 2012, 35, 143-148. [CrossRef]

31. Brailoiu, G.C.; Dun, S.L.; Brailoiu, E.; Inan, S.; Yang, J.; Chang, J.K.; Dun, N.J. Nesfatin-1: Distribution and interaction with a G protein-coupled receptor in the rat brain. Endocrinology 2007, 148, 5088-5094. [CrossRef]

32. Foo, K.S.; Brismar, H.; Broberger, C. Distribution and neuropeptide coexistence of nucleobindin-2 mRNA/nesfatin-like immunoreactivity in the rat CNS. Neuroscience 2008, 156, 563-579. [CrossRef] [PubMed]

33. Fort, P.; Salvert, D.; Hanriot, L.; Jego, S.; Shimizu, H.; Hashimoto, K.; Mori, M.; Luppi, P.H. The satiety molecule nesfatin-1 is co-expressed with melanin concentrating hormone in tuberal hypothalamic neurons of the rat. Neuroscience 2008, 155, 174-181. [CrossRef] [PubMed]

34. Goebel, M.; Stengel, A.; Wang, L.; Lambrecht, N.W.G.; Taché, Y. Nesfatin-1 immunoreactivity in rat brain and spinal cord autonomic nuclei. Neurosci. Lett. 2009, 452, 241-246. [CrossRef] [PubMed] 
35. Kohno, D.; Nakata, M.; Maejima, Y.; Shimizu, H.; Sedbazar, U.; Yoshida, N.; Dezaki, K.; Onaka, T.; Mori, M.; Yada, Y. Nesfatin-1 neurons in paraventricular and supraoptic nuclei of the rat hypothalamus coexpress oxytocin and vasopressin and are activated by refeeding. Endocrinology 2008, 149, 1295-1301. [CrossRef]

36. Okere, B.; Xu, L.; Roubos, E.W.; Sonetti, D.; Kozicz, T. Restraint stress alters the secretory activity of neurons co-expressing urocortin-1, cocaine- and amphetamine-regulated transcript peptide and nesfatin-1 in the mouse Edinger-Westphal nucleus. Brain Res. 2010, 1317, 92-99. [CrossRef]

37. Feijoo-Bandın, S.; Rodrıguez-Penas, D.; Garcıa-Rua, V.; Mosquera-Leal, A.; Otero, M.F.; Pereira, E.; Rubio, J.; Martínez, I.; Seoane, L.M.; Gualillo, O.; et al. Nesfatin-1 in human and murine cardiomyocytes: Synthesis, secretion, and mobilization of GLUT-4. Endocrinology 2013, 154, 4757-4767. [CrossRef]

38. Foo, K.S.; Brauner, H.; Ostenson, C.O.; Broberger, C. Nucleobindin-2/nesfatin in the endocrine pancreas: Distribution and relationship to glycaemic state. J. Endocrinol. 2010, 204, 255-263. [CrossRef]

39. Garcia-Galiano, D.; Pineda, R.; Ilhan, T.; Castellano, M.; Ruiz-Pino, F.; Sánchez-Garrido, M.A.; Vazquez, M.J.; Sangiao-Alvarellos, S.; Romero-Ruiz, A.; Pinilla, L.; et al. Cellular distribution, regulated expression, and functional role of the anorexigenic peptide, NUCB2/nesfatin-1, in the testis. Endocrinology 2012, 153, 1959-1971. [CrossRef]

40. Jiang, L.; Bao, J.; Zhou, X.; Xiong, Y.; Wu, L. Increased serum levels and chondrocyte expression of nesfatin-1 in patients with osteoarthritis and its relation with BMI, hsCRP, and IL-18. Mediators Inflamm. 2013, 2013, 631251. [CrossRef]

41. Kim, J.; Chung, Y.; Kim, H.; Im, E.; Lee, H.; Yang, H. The tissue distribution of nesfatin 1/NUCB2 in mouse. Dev. Reprod. 2014, 18, 301-309. [CrossRef]

42. Puzio, I.; Tymicki, G.; Pawłowska-Olszewska, M.; Bieńko, M.; Radzki, R.P. Nesfatin-1 prevents negative changes in bone in conditions of developing osteopenia. Ann. Agric. Environ. Med. 2020, 27, 66-75. [CrossRef] [PubMed]

43. Stengel, A.; Goebel, M.; Yakubov, I.; Wang, L.; Witcher, D.; Coskun, T.; Taché, Y.; Sachs, G.; Lambrecht, N.W. Identification and characterization of nesfatin-1 immunoreactivity in endocrine cell types of the rat gastric oxyntic mucosa. Endocrinology 2009, 150, 232-238. [CrossRef] [PubMed]

44. Voss, U.; Riva, M.; Dekker, N.M.N.; Ling, C.; Lindqvist, A.; Wierup, N. Nesfatin-1 stimulates insulin secretion, inhibits glucagon secretion and is expressed in human and rodent beta cells. Diabetes 2010, 53, S222.

45. Zhang, A.Q. Expression of nesfatin-1/NUCB2 in rodent digestive system. World J. Gastroenterol. 2010, 16, 1735-1741. [CrossRef] [PubMed]

46. Aydin, S. The presence of the peptides apelin, ghrelin and nesfatin-1 in the human breast milk, and the lowering of their levels in patients with gestational diabetes mellitus. Peptides 2010, 31, 2236-2240. [CrossRef]

47. Zhang, Y.; Shui, X.; Lian, X.; Wang, G. Serum and synovial fluid nesfatin-1 concentration is associated with radiographic severity of knee osteoarthritis. Med. Sci. Monit. 2015, 21, 1078-1082.

48. Scotece, M.; Conde, J.; Abella, V.; López, V.; Lago, F.; Pino, J.; Gómez-Reino, J.J.; Gualillo, O. NUCB2/nesfatin: A new adipokine expressed in human and murine chondrocytes with pro-inflammatory properties, an in vitro study. J. Ortho. Res. 2014, 32, 653-660. [CrossRef]

49. Li, R.; Wu, Q.; Zhao, Y.; Jin, W.; Yuan, X.; Wu, X.; Tang, Y.; Zhang, J.; Tan, X.; Bi, F.; et al. The novel pro-osteogenic activity of NUCB2. PLoS ONE 2013, 8, e61619.

50. Ferretti, J.L.; Capozza, R.F.; Mondelo, N.; Montuori, E.; Zanchetta, J.R. Interrelationships between densitometric, geometric and mechanical properties of rat femora: Inferences concerning mechanical regulation of bone modeling. J. Bone Min. Res. 1993, 8 , 1389-1395. [CrossRef]

51. Lelovas, P.P.; Xanthos, T.T.; Thoma, S.E.; Lyritis, G.P.; Dontas, I.A. The laboratory rat as an animal model for osteoporosis research Comp. Med. 2008, 58, 424-430.

52. Garnero, P.; Sornay-Rendu, E.; Chapuy, M.C.; Delmas, P.D. Increased bone turnover in late postmenopausal women is a major determinant of osteoporosis. J. Bone Miner. Res. 1996, 3, 337-349. [CrossRef] [PubMed]

53. Christiansen, C.; Lindsay, R. Estrogens, bone loss and preservation. Osteoporos. Int. 1990, 1, 7-13. [CrossRef] [PubMed]

54. Levin, V.A.; Jiang, X.; Kagan, R. Estrogen therapy for osteoporosis in the modern era. Osteoporos. Int. 2018, 29, 1049-1055. [CrossRef] [PubMed]

55. Seeman, E. Bone quality. Adv. Osteoporos. Fract. Manag. 2002, 2, 2-8. [CrossRef]

56. Seeman, E.; Delmas, P.D. Bone quality the material and structural basis of bone strength and fragility. N. Engl. J. Med. 2006, 354, 2250-2261. [CrossRef]

57. Ammann, P.; Rizzoli, R. Bone strength and its determinants. Osteoporos. Int. 2003, 14, 13-18. [CrossRef]

58. Dalle Carbonare, L.; Giannini, S. Bone microarchitecture as an important determinant of bone strength. J. Endocrinol. Invest. 2004, 27, 99-105. [CrossRef]

59. Felsenberg, D.; Boonen, S. The bone quality framework: Determinants of bone strength and their interrelationships, and implications for osteoporosis management. Clin. Terap. 2005, 27, 1-11. [CrossRef]

60. Riggs, B.L.; Melton, L.J., III; Robb, R.A.; Camp, J.J.; Atkinson, E.J.; Peterson, J.M.; Rouleau, P.A.; McCollough, C.H.; Bouxsein, M.L.; Khosla, S. Population-based study of sex differences in bone volumetric density, size, geometry, and structure at different skeletal sites. JBMR 2004, 19, 1945-1954. [CrossRef]

61. Chen, G.; Wang, C.; Wang, J.; Yin, S.; Gao, H.; Xiang, L.; Liu, H.; Xiong, Y.; Wang, P.; Zhu, X.; et al. Antiosteoporotic effect of icariin in ovariectomized rats is mediated via the Wnt/ $\beta$-catenin pathway. Exp. Ther. Med. 2016, 12, 279-287. [CrossRef] 
62. Malik, S.S.; Malik, S.; Shenoy, R.; Jones, M.D. Theobald P.S. An in-vitro animal bone model study to predict spiral fracture strength of long bones in the young infant. J. Clin. Orthop. Trauma. 2019, 10, 744-749. [CrossRef] [PubMed]

63. Puzio, I.; Graboś, D.; Bieńko, M.; Radzki, R.P.; Nowakiewicz, A.; Kosior-Korzecka, U. Camelina oil supplementation improves bone parameters in ovariectomized rats. Animals 2021, 11, 1343. [CrossRef] [PubMed]

64. Wang, F.; Wang, P.X.; Wu, X.L.; Dang, S.; Chen, Y.; Ni, Y.; Gao, L.; Lu, S.; Kuang, Y.; Huang, L.; et al. Deficiency of adiponectin protects against ovariectomy-Induced osteoporosis in mice. PLoS ONE 2013, 8, e68497. [CrossRef] [PubMed]

65. Haugen, S.; He, J.; Sundaresan, A.; Stunes, A.K.; Aasarød, K.M.; Tiainen, H.; Syversen, U.; Skallerud, B.; Reseland, J.E. Adiponectin reduces bone stiffness: Verified in a three-dimensional artificial human bone model in vitro. Front. Endocrinol. 2018, 9, 236. [CrossRef]

66. Kuo, T.R.; Chen, C.H. Bone biomarker for the clinical assessment of osteoporosis: Recent developments and future perspectives. Biomark. Res. 2017, 5, 18. [CrossRef]

67. Swaminathan, R. Biochemical markers of bone turnover. Clin. Chim. Acta 2001, 313, 95-105. [CrossRef]

68. Ivaska, K.K.; Hentunen, T.A.; Vääräniemi, J.; Ylipahkala, H.; Pettersson, K.; Väänänen, H.K. Release of intact and fragmented osteocalcin molecules from bone matrix during bone resorption in vitro. J. Biol. Chem. 2004, 279, 18361-18369. [CrossRef]

69. Venkateshaiah, S.U.; Khan, S.; Ling, W.; Bam, R.; Li, X.; van Rhee, F.; Usmani, S.; Barlogie, B.; Epstein, J.; Yaccoby, S. NAMPT/PBEF1 enzymatic activity is indispensable for myeloma cell growth and osteoclast activity. Exp. Hematol. 2013, 41,547-557. [CrossRef]

70. Laiguillon, M.C.; Houard, X.; Bougault, C.; Gosset, M.; Nourissat, G.; Sautet, A.; Jacques, C.; Berenbaum, F.; Sellam, J. Expression and function of visfatin (Nampt), an adipokine-enzyme involved in inflammatory pathways of osteoarthritis. Arthritis Res. Ther. 2014, 16, R38. [CrossRef]

71. Luo, X.H.; Guo, L.J.; Xie, H.; Yuan, L.Q.; Wu, X.P.; Zhou, H.D.; Liao, E.Y. Adiponectin stimulates RANKL and inhibits OPG expression in human osteoblasts through the MAPK signaling pathway. J. Bone Miner. Res. 2006, 21, 1648-1656. [CrossRef]

72. Yamaguchi, N.; Kukita, T.; Li, Y.J.; Kamio, N.; Fukumoto, S.; Nonaka, K.; Ninomiya, Y.; Hanazawa, S.; Yamashita, Y. Adiponectin inhibits induction of TNF-alpha/RANKL-stimulated NFATc1 via the AMPK signaling. FEBS Lett. 2008, 582, 451-456. [CrossRef] [PubMed]

73. Williams, G.A.; Wang, Y.; Callon, K.E.; Watson, M.; Lin, J.M.; Lam, J.B.; Costa, J.L.; Orpe, A.; Broom, N.; Naot, D.; et al. In vitro and in vivo effects of adiponectin on bone. Endocrinology 2009, 150, 3603-3610. [CrossRef] [PubMed]

74. Wang, Q.P.; Li, X.P.; Wang, M.; Zhao, L.L.; Li, H.; Xie, H.; Lu, Z.Y. Adiponectin exerts its negative effect on bone metabolism via OPG/RANKL pathway: An in vivo study. Endocrine 2014, 47, 845-853. [CrossRef] [PubMed]

75. Lee, Y.A.; Ji, H.I.; Lee, S.H.; Hong, S.J.; Yang, H.I.; Yoo, M.M.; Kim, K.S. The role of adiponectin in the production of IL-6, IL-8, VEGF and MMPs in human endothelial cells and osteoblasts: Implications for arthritic joints. Exp. Mol. Med. 2014, 46, e72. [CrossRef]

76. Junkera, S.; Frommera, K.W.; Krumbholza, G.; Tsiklauria, L.; Gerstbergerb, R.; Rehartc, S.; Steinmeyerd, J.; Rickertd, M.; Wenische, S.; Schett, G.; et al. Expression of adipokines in osteoarthritis osteophytes and their effect on osteoblasts. Matrix Biol. 2017, 62, 75-91. [CrossRef]

77. Kudo, O.; Fujikawa, Y.; Itonaga, I.; Sabokbar, A.; Torisu, T.; Athanasou, N.A. Proinflammatory cytokine (TNF $\alpha / \mathrm{IL}-1 \alpha)$ induction of human osteoclast formation. J. Pathol. 2002, 198, 220-227. [CrossRef]

78. Bendre, M.S.; Montague, D.C.; Peery, T.; Akel, N.S.; Gaddy, D.; Suva, L.J. Interleukin-8 stimulation of osteoclastogenesis and bone resorption is a mechanism for the increased osteolysis of metastatic bone disease. Bone 2003, 33, 28-37. [CrossRef]

79. Pino, A.M.; Ríos, S.; Astudillo, P.; Fernández, M.; Figueroa, P.; Seitz, G.; Rodríguez, J.P. Concentration of adipogenic and proinflammatory cytokines in the bone marrow supernatant fluid of osteoporotic women. JBMR 2010, 25, 492-498. [CrossRef]

80. Moon, S.J.; Ahn, I.E.; Jung, H.; Yi, H.; Kim, J.; Kim, Y.; Kwok, S.K.; Park, K.S.; Min, J.K.; Park, S.H.; et al. Temporal differential effects of proinflammatory cytokines on osteoclastogenesis. Int. J. Mol. Med. 2013, 31, 769-777. [CrossRef]

81. Berner, H.S.; Lyngstadaas, S.P.; Spahr, A.; Monjo, M.; Thommesen, L.; Drevon, C.A.; Syversen, U.; Reselan, J.E. Adiponectin and its receptors are expressed in bone-forming cells. Bone 2004, 35, 842-849. [CrossRef]

82. Huang, C.Y.; Lee, C.Y.; Chen, M.Y.; Tsai, H.C.; Hsu, H.C.; Tang, C.H. Adiponectin increases BMP-2 expression in osteoblasts via AdipoR receptor signaling pathway. J. Cell Physiol. 2010, 224, 475-483. [CrossRef] [PubMed]

83. Kanazawa, I. Adiponectin in metabolic bone disease. Curr. Med. Chem. 2012, 19, 5481-5492. [CrossRef] [PubMed]

84. Philp, A.M.; Collier, R.L.; Grover, L.M.; Davis, E.T.; Jones, S.W. Resistin promotes the abnormal Type I collagen phenotype of subchondral bone in obese patients with end stage hip osteoarthritis. Sci. Rep. 2017, 7, 4042. [CrossRef] [PubMed]

85. Xie, H.; Tang, S.Y.; Luo, X.H.; Huang, J.; Cui, R.R.; Yuan, L.Q.; Zhou, H.D.; Wu, X.P.; Liao, E.Y. Insulin-like effects of visfatin. on human osteoblasts. Calcif. Tissue Int. 2007, 80, 201-210.

86. Li, Y.; He, J.; He, X.; Lindgren, U. Nampt expression increases during osteogenic differentiation of multi- and omnipotent progenitors. Biochem. Biophys. Res. Commun. 2013, 434, 117-123. [CrossRef]

87. Briana, D.D.; Boutsikou, M.; Boutsikou, T.; Malamitsi-Puchner, A. Associations of novel adipocytokines with bone biomarkers in intra uterine growth-restricted fetuses/neonates at term. J. Matern. Fetal Neonatal. Med. 2014, 27, 984-988. [CrossRef] 
88. Conde, J.; Gomez, R.; Bianco, G.; Scotece, M.; Lear, P.; Dieguez, C.; Gomez-Reino, J.; Lago, F.; Gualillo, O. Expanding the adipokine network in cartilage: Identification and regulation of novel factors in human and murine chondrocytes. Ann. Rheum. Dis. 2011, 70, 551-559. [CrossRef]

89. Muruganandan, S.; Roman, A.A.; Sinal, C.J. Role of chemerin/CMKLR1 signaling in adipogenesis and osteoblastogenesis of bone marrow stem cells. J. Bone Miner. Res. 2010, 25, 222-234. [CrossRef] 